\title{
Three new species of Cymbella (Bacillariophyta) from high altitude lakes, China
}

\author{
Zhujun Hu${ }^{1,2}$, YANLing Li ${ }^{1 *}$, DitMar MetZeltin ${ }^{3}$ \\ ${ }^{1}$ State Key Laboratory of Lake Science and Environment, Nanjing Institute of \\ Geography and Limnology, Chinese Academy of Sciences, Nanjing 210008, \\ People's Republic of China \\ ${ }^{2}$ University of Chinese Academy of Science, Beijing 100049, People's Republic of China \\ ${ }^{3}$ Am Stegskreuz 3b, D-65719 Hofheim, Germany
}

\begin{abstract}
This paper describes three new Cymbella species from high altitude lakes of Hengduan Mountains region, southwest China. Cymbella heihainensis Li et Gong nov. spec. is similar to C. modicepunctata Krammer, C. asiatica Metzeltin, Lange-Bertalot et $\mathrm{Li}, \mathrm{Y}$., but differs from them in valve size, stigmata, raphe ending and also striae number. Cymbella shudunensis Li et Metzeltin nov. spec. is related to C. terrafuegiana, but differs in wider valve size, larger central area and coarser puncta. $C$. shudunensis differs from $C$. proxima Reimer in Patrick et Reimer group in reverse lateral raphes at the proximal endings, and distinguished from C.cistula (Ehrenberg) O.Kirchner group in the absent central area on dorsal side. Cymbella xingyunnensis Li and Gong sp. nov. resembles the group around C. proxima, and the most similar taxon is $C$. sinensis Metzeltn et Krammer, which can be distinguished by its lack of stigmata.
\end{abstract}

Key words: Cymbella heihainensis, Cymbella shudunensis, Cymbella xingyunnensis, diatoms, China

\section{Introduction}

The global warming and nitrogen deposition in the last century have enriched lakes on the hemispheric scale, and resulted in a loss of biodiversity in natural habitats (ABER et al. 1995). As is well known, high altitude lakes are an important part of natural ecosystems. Southeast Asia is becoming a hot spot because of its unique topographic character and the increasing anthropogenic disturbance (GALLOWAY and COWLING 2002). Diatom community is used as a main indicator of environmental and biodiversity change, both in limnology and palaeolimnology (SMOL and STOERMER 2010).

\footnotetext{
* Corresponding author, e-mail: ylli@niglas.ac.cn

Copyright ${ }^{\circledR} 2013$ by Acta Botanica Croatica, the Faculty of Science, University of Zagreb. All rights reserved.
} 
There is limited investigation of freshwater diatoms in SE Asia. Among species of the genus Cymbella, 49 were reported from northeastern China (FAN et al. 1993, BAO et al. 1992), 8 from Xingjiang Province, NW China (You et al. 2005, 2008), 44 from India (JENA et al. 2006, NAutiYAl et al. 2004), and 9 from Japan (HiRANo 1972). One new variety of Cymbella was described from Qinghai Province, NW China (LI et al. 2003b). In the Himalayan region, 4 new species of Cymbella from alpine lakes and springs have been reported from Everest National Park of Nepal (JÜTTNER et al. 2010, 2000). There were also studies on cymbelloid diatoms near Mount Everest in China (Li et al. 2004, 2007b), showing that 44 species belong to Cymbella, of them 16 new records, some of them unique to this region. One new species of Cymbella has been found from northwest Tibet (Li et al. 2003a), and one from the Far East (LEE et al. 1993), respectively. Also, a few studies have been carried out on the diatoms from the Hengduan Mountains region, SW China (SKUJA 1937, ZHu and CHEN 1994, Li et al. 2003c, Li et al. 2007a). One Cymbella species was found that is unique to this area (LI et al. 2007a), and some taxa belonging to Cymbella are found that have different morphological features compared with previously published descriptions (LI et al. 2003c).

In this paper we describe three Cymbella species new to science from three high altitude lakes in the Hengduan Mountains Region. One is related to C. modicepunctata Krammer and similar species; one is similar to C. terrafuegiana Krammer; and we also give a detailed morphological description of a new taxon similar to C. sinensis Metzeltn et Krammer.

\section{Study area}

The Hengduan Mountains region $\left(23-33^{\circ} \mathrm{N}, 97-103^{\circ} \mathrm{E}\right)$ comprises western Sichuan Province, western Yunnan Province and part of eastern Tibet, southwest China. The area is about 0.5 million $\mathrm{km}^{2}$ (ZHANG 1997). This region is a transitional zone between lowland tropical and subtropical climate zones because of the uplift of Tibetan Plateau (YANG 1983). The elevation ranges from more than $5000 \mathrm{~m}$ a.s.1. to less than $2000 \mathrm{~m}$ a.s.l. It is predominantly affected by the SW Asian monsoon from India in summer (CHEN 1998). Plentiful monsoon precipitation promotes the development of forest, and its topographic complexity. Besides, the unique geologic history makes this region become one of the world's biodiversity hotspots (FAN et al. 2012, MYERS et al. 2000). Thus there are rich flora and fauna in this area, including many relict diatom species (Li et al. 2007a). The high altitude lakes located are important reservoirs of regional biodiversity.

\section{Methods}

Samples were taken from the surface sediments of Heihai Lake (Tab. 1), Shudu Lake and Xingyun Lake with the use of a Kajak gravity corer in the deepest part of the lakes. Heihai Lake is above the tree line, the catchment is characterized by alpine meadows; Shudu Lake is located within the alpine/sub-alpine ecotone with the catchment primarily consisting of PicealAbies, while Xingyun Lake is situated within subtropical evergreen coniferous and broad-leaved mixed forest, dominated by Pinus yunnanensis.

Diatom samples were kept under $4{ }^{\circ} \mathrm{C}$ in refrigerator before laboratory treatment. They were treated with $\mathrm{HCl}$ and $\mathrm{H}_{2} \mathrm{O}_{2}$ (YANG et al. 2008). Permanent slides were made from cleaned materials and mounted in Naphrax ${ }^{\circledR}$ for observation with light microscopy (Olym- 
Tab. 1. Location and environmental characteristics of the three lakes.

\begin{tabular}{lccc}
\hline & Heihai Lake & Shudu Lake & Xingyun Lake \\
\hline Latitude $\left({ }^{\circ} \mathrm{N}\right)$ & $27^{\circ} 21^{\prime}$ & $27^{\circ} 54^{\prime}$ & $24^{\circ} 20^{\prime}$ \\
Longitude $\left({ }^{\circ} \mathrm{E}\right)$ & $100^{\circ} 04^{\prime}$ & $99^{\circ} 57^{\prime}$ & $102^{\circ} 47^{\prime}$ \\
Altitude $(\mathrm{m})$ & 4117 & 3630 & 1748 \\
Lake area $\left(\mathrm{km}^{2}\right)$ & 0.18 & 1.70 & 34.71 \\
Maximum depth $(\mathrm{m})$ & 42.4 & 7.8 & 8.3 \\
$\mathrm{pH}$ & 7.79 & 7.77 & 9.15 \\
$\mathrm{SD}(\mathrm{m})$ & 4.5 & 0.8 & 0.9 \\
$\mathrm{TN}\left(\mathrm{mg} \mathrm{L}^{-1}\right)$ & 0.26 & 1.52 & 1.22 \\
$\mathrm{TP}\left(\mathrm{mg} \mathrm{L}^{-1}\right)$ & 0.013 & 0.036 & 0.263 \\
Conductivity $\left(\mathrm{ms} \mathrm{cm}^{-1}\right)$ & 57 & 31.6 & 410 \\
\hline
\end{tabular}

pus, BX-51, DIC). Cleaned materials were also investigated with a Leo 1530 scanning electron microscope (SEM). At least 500 valves were counted in each surface sediment sample. Lake water $\mathrm{pH}$ and specific conductance were measured in the field using a YSI 650 multi-parameter display system (650 MDS, YSI Incorporated 1700/1725 Brannum Lane, Yellow Springs, OH 45387 USA) with a 600XL probe. Water samples were taken from about $50 \mathrm{~cm}$ under the surface. Total nitrogen (TN) and total phosphorus (TP) were measured by a Shimadzu UV2450 ultraviolet-visible spectrophotometer at Nanjing Institute of Geography and Limnology, Chinese Academy of Sciences, using alkaline potassium persulfate digestion-UV spectrophotometric method (NYDAHL 1978) and ammonium molybdate spectrophotometry method (EBINA et al. 1983), respectively.

\section{Results}

\section{Cymbella heihainensis Li et Gong nov. spec.}

Figs. 1-6. Fig. 1 is of the holotype.

Description: Valves are strongly dorsiventral. Dorsal margins strongly convex, ventral margins slightly to moderately concave and slightly tumid in the middle. Ends are bluntly rounded. Length 82-105 $\mu \mathrm{m}$, breadth 19-22.5 $\mu \mathrm{m}$, maximal length/breadth is about 4.7. Raphe is at middle line of valve, strongly lateral, and becoming slightly reverse-lateral near the proximal ends. Axial area is moderately broad. Central area is orbicular to broadly elliptical, about $1 / 2$ breadth of the valve. Striae slightly radiate in the middle portion, and radiate more towards the end, coarsely punctuate. 7-10 stigmata surrounding the ventral side on the central area separated from the shortened ventral striae by a narrow hyaline area, sometimes there are several smaller stigmata between the main stigmata and the middle ventral striae (Fig. 2), on dorsal side, 0-3 stigmata distance from the shortened striae (Figs. 1, 3). Striae $7-8 / 10 \mu \mathrm{m}$ in the middle, and becoming $8-10 / 10 \mu \mathrm{m}$ towards the distal, with 14-16 areolae in $10 \mu \mathrm{m}$. In SEM external valve view: proximal and distal raphe endings deflected on ventral side, raphe slit is located on a rib and thickened part of the centre axial areas, expanded drop-like central pores at proximal raphe ends (Figs. 4, 6); the distal raphe endings are question mark-shaped and dorsally deflected, terminating in a large apical pore 


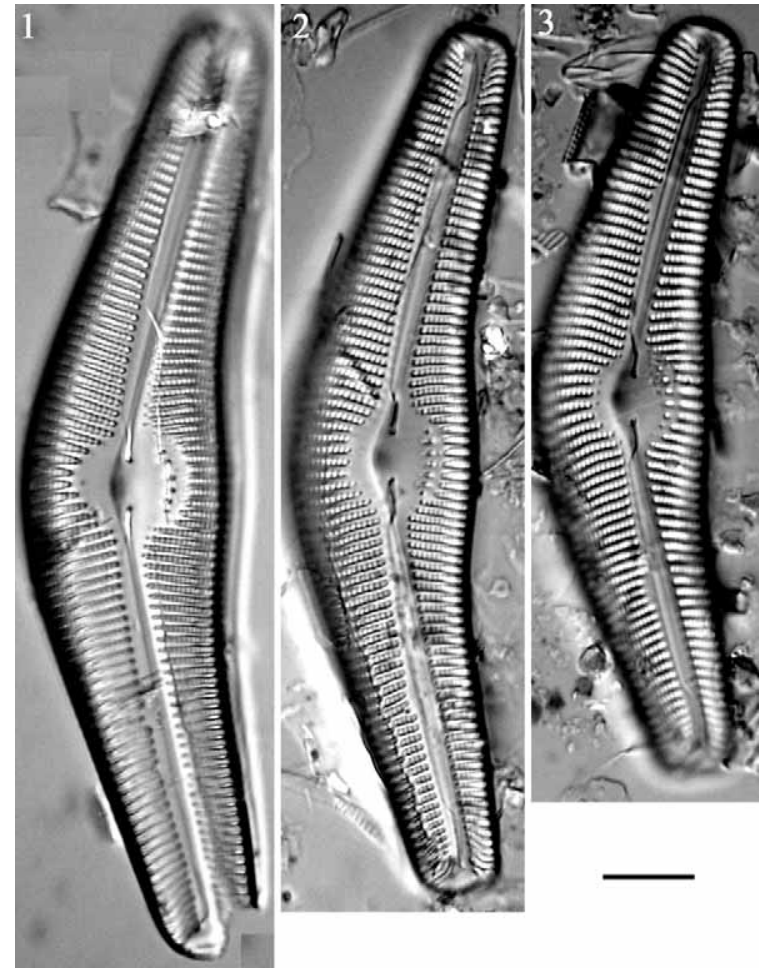

Figs. 1-3. Cymbella heihainensis. Light microscopy, valve views showing size diminution series for the species. Figure 1 is the holotype. Scale bar denotes $10 \mu \mathrm{m}$.

with a big hyaline area on the ventral side of the raphe slit, and small, round pore foramina are arranged irregularly at the margin pole fields (Fig. 5); 6-7 large main stigma foramina on the ventral side of the central nodule, and a second row of some roundish smaller pores is present between the stigmata and the median ventral striae (Fig. 6); striae composed of slit-like areolae becoming shortened, Y-, X- or irregular round shaped towards centre and margin of the valve (Figs. 5, 6).

Distribution: Heihai Lake, which is slightly alkaline and oligotrophic with low TN and TP concentration (Tab. 1).

Typus: Praep. Heihai-1, Nanjing Institute of Geography and Limnology, Chinese Academy of Sciences (NIGLAS).

Locus typicus: Heihai Lake (27²1'19.3”N, $\left.100^{\circ} 04^{\prime} 12.1^{\prime \prime}\right), 11^{\text {th }}$ September, 2007, surface sediment, leg. Dr. Rong Wang.

\section{Cymbella shudunensis Li et Metzeltin nov. spec.}

Figs. 7-13. Fig. 7 is of the holotype.

Description: Valves are strongly dorsiventral and triangle. Dorsal margin is strongly arched. Ventral margin is slightly concave with slightly tumid central part. Valve ends broadly rounded, not protracted. Length 55-87 $\mu \mathrm{m}$ and width 24-27 $\mu \mathrm{m}$, the maximal 




Figs. 4-6. Cymbella heihainensis. SEM, external valve views. Fig. 4 - entire valve view showing the proximal and distal raphe endings ventrally deflected, raphe is located on a thickened part of the centre axial areas. Scale bar denotes $10 \mu \mathrm{m}$. Fig. 5 - view of the pole with question mark-shaped raphe ending, pore foramina are arranged irregularly at the margin pole fields. Scale bar denotes $2 \mu \mathrm{m}$. Fig. 6 - central portion of the valve showing enlarged proximal raphe ends and six rounded bigger stigma openings with some smaller circular stigma near the shortened striae on ventral side, sometimes small round stigmata which are differ from areolae present on the dorsal side. Striae composed of silt-like areolae and becoming X- or Y-shaped towards centre and margin of the valve, the Y- shaped areolae are illustrate with arrows and one X-shaped areolae is pointed with dashed line arrow. Scale bar denotes $2 \mu \mathrm{m}$.

length/width ratio is about 3.3. Axial area is narrow, nearly linear, and the two branches form an obtuse angle. Central area is rounded, and dorsal side is smaller than ventral side. Raphe is strongly ventrally displaced as the axial area, distinctly lateral, becoming filiform near the distal and slightly reverse-lateral near the proximal ends. Central pores small, ventrally bent, terminal fissures dorsally deflected. Striae slightly radiate and become more radiate towards the valve ends. Some short striae arranged on the convex dorsal side in the middle of the valve. 2-4 stigmata appear ventrally from the central nodule, and distant from the middle ventral striae. Striae $7-10 / 10 \mu \mathrm{m}$ in the middle and becoming $10-12 / 10 \mu \mathrm{m}$ towards the distal, with 17-19 areolae in $10 \mu \mathrm{m}$. In SEM external valve view: striae composed of elliptical areolae extending to the mantle, and becoming more rounded towards the valve centre and the valve margin, the striae on the convex dorsal middle part are slightly undulating (Figs. 11, 12); round central pores at proximal raphe ends (Fig. 12); roundish stigma foramina, arranged distant from the foramina of the areolae at central area on ventral side (Figs. 11, 12); scythe-shaped in an angle of $90^{\circ}$ at terminal fissures (Fig. 13). 


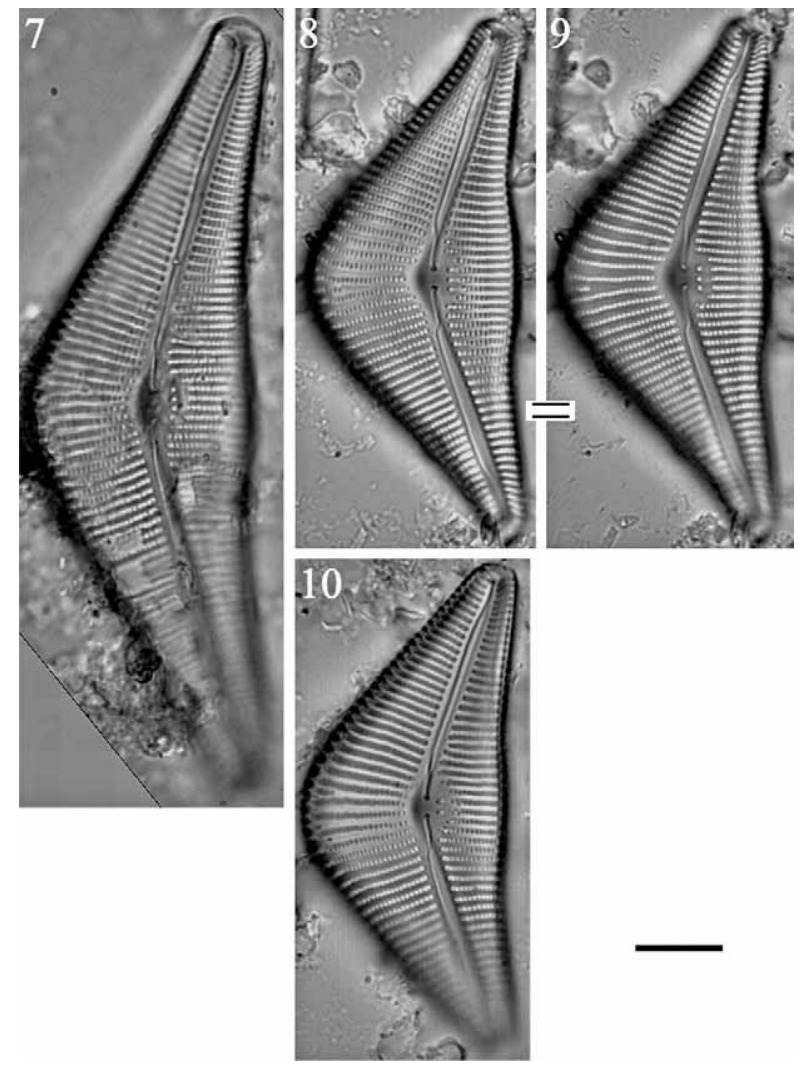

Figs. 7-10. Cymbella shudunensis. Light microscopy. Fig. 7 is the holotype. Figs. 8, 9 - the same valve at different focus. Scale bar denotes $10 \mu \mathrm{m}$.

Distribution: Shudu Lake, China. This lake is characterized by high total nitrogen, low total phosphorus concentration, and also low specific conductance (Tab.1).

Typus: Praep. Shudu-1, Nanjing Institute of Geography and Limnology, Chinese Academy of Sciences (NIGLAS).

Locus typicus: Shudu Lake (2754'36.9’'N, 9956'58.4”), $15^{\text {th }}$ September, 2007, surface sediment, leg. Dr. Rong Wang.

\section{Cymbella xingyunnensis Li et Gong sp. nov.}

Figs. 14-32. Fig. 14 is of the holotype.

Description: Valves are strongly dorsiventral, and broadly lanceolate. Dorsal margin is strongly arched. Ventral margin is straight or slightly concave with slightly tumid central part. Valve ends are narrow, rounded, not protracted. Length $25-41 \mu \mathrm{m}$, width $11.5-13.5$ $\mu \mathrm{m}$, the maximal length/width ratio is about 3.0. Axial area is narrow, and nearly linear. Central area is small and orbicular, developed more on the ventral side. Raphe is nearly in the midline or slightly ventrally displaced, moderately lateral, becoming filiform near the distal and the proximal ends. Central pores indistinct in LM, and terminal fissures dorsally 

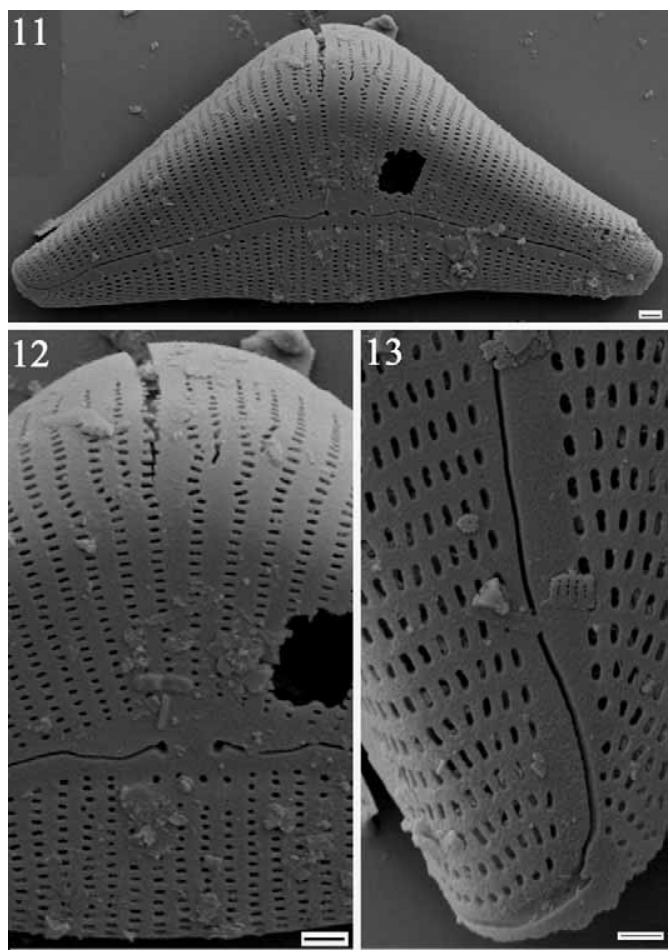

Figs. 11-13. Cymbella shudunensis. SEM, external valve views. Fig. 11 - whole valve view showing striae composed of elliptical areolae extending to the mantle, and becoming more rounded towards the valve centre and the valve margin. Scale bar denotes $2 \mu \mathrm{m}$. Fig. 12 - valve centre with drop-like proximal raphe ends and four roundish stigma opening. v $2 \mu \mathrm{m}$. Fig. 13 - pole field with an angle of almost $90^{\circ}$ scythe-shaped terminal raphe end. Scale bar denotes $1 \mu \mathrm{m}$.

deflected with big pole area. Striae radiate, distinctly punctuate-lineolate. One big stigma appears on the ventral side of the central nodule. Striae $12-14 / 10 \mu \mathrm{m}$ in the middle and becoming 14-16/10 $\mu \mathrm{m}$ towards the distal, with 22-25 areolae in $10 \mu \mathrm{m}$. In SEM external valve view: elongated areolae combined the striae and extending onto the mantle, becoming round towards the central area (Figs. 27); terminal fissures dorsally bent off in an angle of nearly $60^{\circ}$, and small roundish foramina arranged in lines around the pole (Fig. 28); one large, long stigma foramina at central area, expanded drop-like central pores at proximal raphe ends (Fig. 29). In SEM internal valve view: striae with internal areolae openings, and no papillae are present on the areolae inside (Fig. 30); the distal raphe endings dorsally curved, knob-like helictoglossae with parallel arranged pole field alveoli (Fig. 31); central area formed a small hock in proximal raphe ends, one large stigma alveoli with irregular structures near the shorten striae on the ventral side (Fig. 32).

Distribution: Xingyun Lake, China. It is an alkaline, eutrophic lake with relative high specific conductance (Tab. 1). Erhai Lake, China.

Typus: Praep. Xingyun-2, Nanjing Institute of Geography and Limnology, Chinese Academy of Sciences (NIGLAS). 

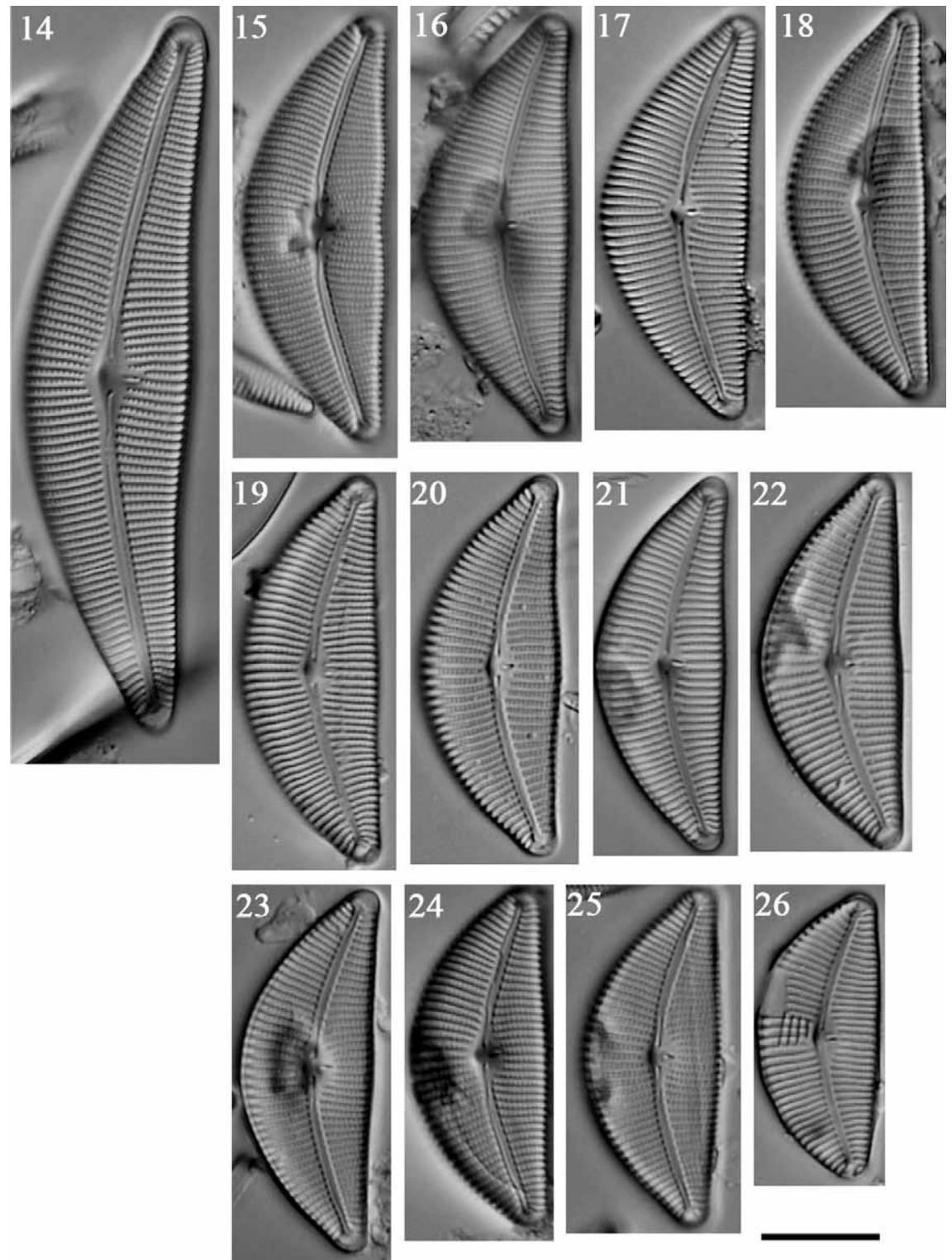

Figs. 14-26. Cymbella xingyunnensis. Light microscopy, valve views showing size reduction. Fig. 14 is the holotype. Scale bar denotes $10 \mu \mathrm{m}$.

Locus typicus: Lake Xingyun in China, (24²1'35.9'N, 102 $\left.46^{\prime} 33.0^{\prime \prime}\right), 4^{\text {th }}$ September, 2007, surface sediment, leg. Dr. Rong Wang. 


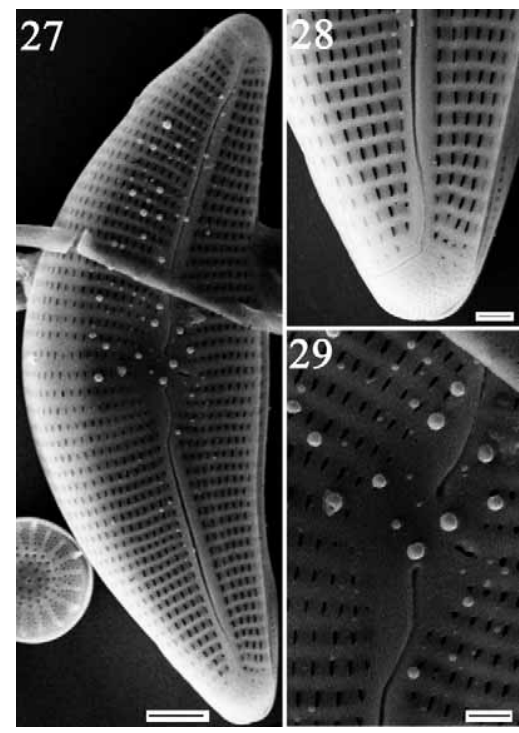

Figs. 27-29. Cymbella xingyunnensis. SEM, external valve views. Fig. 27 - whole valve view showing the striae composed of elongated elliptical areolae extending onto the mantle. Scale bar denotes $3 \mu \mathrm{m}$. Fig. 28 - view of valve end with an angle of nearly $60^{\circ}$ dorsally bent terminal raphe ending and small roundish areolae present in lines around the pole. Scale bar denotes $1 \mu \mathrm{m}$. Fig. 29 - central portion of the valve showing drop-like proximal raphe ends and long stigma opening. Scale bar denotes $1 \mu \mathrm{m}$.

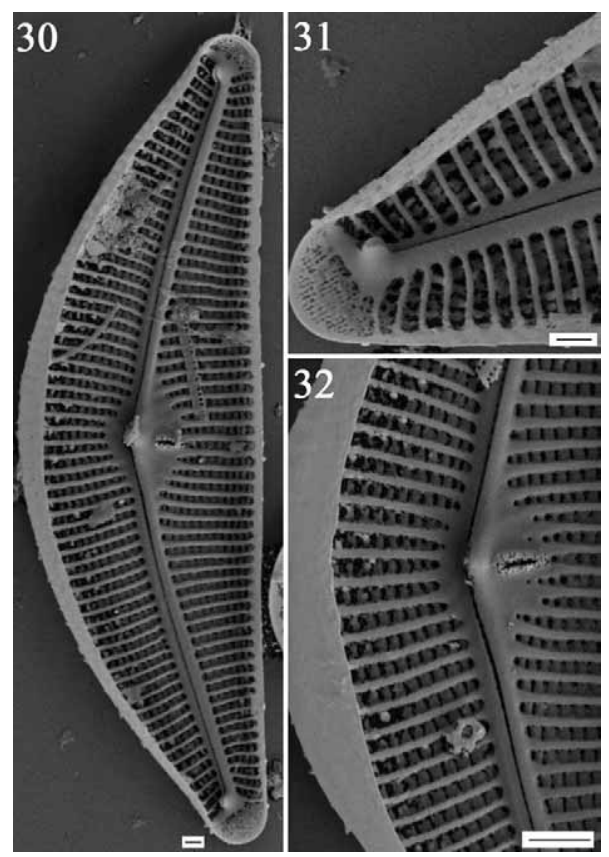

Figs. 30-32. Cymbella xingyunnensis. SEM, internal valve views. Fig. 30 - internal valve view shows striae are a composite of internal areolae openings without papillae. Scale bar denotes $1 \mu \mathrm{m}$. Fig. 31 valve ends with dorsally curved knob-like helictoglossae and parallel alveoli are arranged on the pore field. Scale bar denotes $1 \mu \mathrm{m}$. Fig. 32 - On the central area of the valve, proximal raphe ends form a small hook, and the margins of the stigma alveoli are surrounded with irregular structures. Scale bar denotes 2 $\mu \mathrm{m}$.

\section{Discussion}

\section{Taxonomy}

Cymbella heihainensis appears closely allied to C. modicepunctata and C. asiatica Metzeltin, Lange-Bertalot et Li, Y. (Krammer 2002, Metzeltin et al. 2009) (Tab. 2). The most similar taxon is $C$. modicepunctata: it has larger valve size, bigger central area, and more striae in $10 \mu \mathrm{m}$, distinguishing it from $C$. heihainensis. Cymbella heihainensis has bigger stigmata near the central area and smaller ones near the middle striae ventrally and sometimes stigmata on dorsal side, but $C$. modicepunctata only has the same size stigmata on the ventral side. The same stigmata feature of $C$. heihainensis is also found in $C$. schimanskii and its variety var. excelsa (Meister) Krammer. In SEM view, C. schimanskii 
Tab. 2. Morphological characters of Cymbella heihainensis Li et Gong, C. modicepunctata Krammer, C. asiatica Metzeltin, Lange-Bertalot et Li, Y., C. schimanskii Krammer and $C$. arctissima Metzeltin.

\begin{tabular}{|c|c|c|c|c|c|}
\hline \multirow[b]{2}{*}{$\begin{array}{l}\text { Species/ } \\
\text { Feature }\end{array}$} & \multirow{2}{*}{$\begin{array}{c}\text { New species } \\
\text { C. heihainensis } \\
\text { Li et Gong }\end{array}$} & \multicolumn{4}{|c|}{ Species for comparison } \\
\hline & & $\begin{array}{l}\text { C. modice- } \\
\text { punctata } \\
\text { Krammer }\end{array}$ & $\begin{array}{c}\text { C. asiatica } \\
\text { Metzeltin, } \\
\text { Lange-Bertalot } \\
\text { et } \mathrm{Li}, \mathrm{Y} \text {. }\end{array}$ & $\begin{array}{l}\text { C. schimanskii } \\
\text { Krammer }\end{array}$ & $\begin{array}{l}\text { C. arctissima } \\
\text { Metzeltin }\end{array}$ \\
\hline $\begin{array}{l}\text { Valve length, } \\
\mu \mathrm{m}\end{array}$ & $82-100$ & $102-140$ & $50-105$ & $100-200$ & $98-105$ \\
\hline $\begin{array}{l}\text { Valve width, } \\
\mu \mathrm{m}\end{array}$ & $19-22.5$ & $21-22$ & $14-18$ & $29-36$ & $17-18$ \\
\hline $\begin{array}{l}\text { Length/width } \\
\text { ratio }\end{array}$ & 4.7 & $\max 6.4$ & $\max 5.8$ & $\max 5$ & $\max 5.8$ \\
\hline $\begin{array}{l}\text { Striae in } \\
10 \mu \mathrm{m}\end{array}$ & $7-10$ & $5.5-6$ & $6-7$ & $7-12$ & $7-10$ \\
\hline $\begin{array}{l}\text { Areolae in } \\
10 \mu \mathrm{m}\end{array}$ & $14-16$ & $14-16$ & $18-22$ & $10-16$ & $18-21$ \\
\hline Areolae & $\begin{array}{c}\text { Slit-like, } \\
\text { Y-, X- shaped }\end{array}$ & Lineolate & not known & $\begin{array}{l}\text { Slit-like, } \\
\text { Y-shaped }\end{array}$ & Slit-like \\
\hline Stigmata & $\begin{array}{l}\text { ventral side: } \\
7-10 \text { big and } \\
\text { some smaller, } \\
\text { dorsal side: } 0-5\end{array}$ & $\begin{array}{l}\text { ventral side: } \\
7-10\end{array}$ & $\begin{array}{c}\text { ventral side: } \\
4-6\end{array}$ & $\begin{array}{l}\text { ventral side: } \\
6-10 \text { big and } \\
\text { some smaller, } \\
\text { dorsal side: } \\
\text { sometimes some }\end{array}$ & $\begin{array}{l}\text { ventral side: } \\
\quad 6-8\end{array}$ \\
\hline Central area & $1 / 2$ width & 2/3-3/4 width & $1 / 2$ width & $1 / 3$ width & $2 / 3$ width \\
\hline $\begin{array}{l}\text { Central raphe } \\
\text { endings }\end{array}$ & $\begin{array}{c}\text { expanded } \\
\text { drop-like, } \\
\text { slightly ventrally } \\
\text { deflected }\end{array}$ & $\begin{array}{l}\text { distinct, very } \\
\text { slightly } \\
\text { reverse-lateral }\end{array}$ & $\begin{array}{l}\text { distinct, abruptly } \\
\text { reverse-lateral }\end{array}$ & $\begin{array}{l}\text { small, slightly } \\
\text { reverse-lateral }\end{array}$ & $\begin{array}{l}\text { small, dorsally } \\
\text { deflected }\end{array}$ \\
\hline Reference & This study & $\begin{array}{l}\text { KRAMMER } \\
\text { (2002) }\end{array}$ & $\begin{array}{l}\text { METZELTIN } \\
\text { et al. (2009) }\end{array}$ & $\begin{array}{l}\text { KRAMMER } \\
\text { (2002) }\end{array}$ & $\begin{array}{l}\text { KRAMMER } \\
(2002)\end{array}$ \\
\hline
\end{tabular}

has Y-shaped areolae openings in the middle of the valve and elsewhere they are slit-like, which is similar to the case of $C$. heihainensis, and the raphe is also located on a rib and thickened part (Pl. 79, Figs. 1-3 in KRAMMER 2002). However, they differ from $C$. heihainensis in the bigger valve size and smaller central area, also in the central pores (roundish shaped vs expanded drop- as in C. heihainensis). C. sturii Grunow has stigmata on both side, but the ventral stigmata are the same size. $C$. heihainensis can be distinguished from $C$. asiatica in valve size, shape of ends and stigmata numbers. Cymbella asiatica varies between 50 and $105 \mu \mathrm{m}$ in length and $14-18 \mu \mathrm{m}$ in width, with broadly rounded ends, 4-6 stigmata on the ventral side and no stigmata on the dorsal side. C. heihainensis is also similar to $C$. arctissima Metzeltin, which can be separated by dorsally deflected proximal raphe endings, thinner (17-18 $\mu \mathrm{m}$ vs. 19-22.5 $\mu \mathrm{m})$ valve size and finer punctuate (18-21/ $10 \mu \mathrm{m}$ vs. $14-16 / 10 \mu \mathrm{m})$. 
Based on the morphological characters, $C$. shudunensis belongs to the group around $C$. cymbiformis Agardh (e.g. indistinct central area on dorsal side, less than 20 puncta in $10 \mu \mathrm{m}$, and 1-6 stigma). Cymbella shudunensis differs from $C$. proxima Reimer in Patrick et Reimer group in reverse lateral raphes at the proximal endings, and can be distinguished from C.cistula (Ehrenberg) O. Kirchner group in the absent central area on dorsal side. The outline shape of this species is rare, as it is in all the similar species (Tab. 3). The taxon most similar to $C$. shudunensis is $C$. terrafuegiana which belongs to $C$. cymbiformis group with strongly dorsiventral broadly semirhomboid. The outline of $C$. shudunensis is more convex than C. terrafuegiana on a wider valve size, larger central area and coarser puncta (Tab. 3). The similar taxa C. proxima (Pl. 112, Figs. 1-6b in KRAMMER 2002), C. baicalensis Skvortzow et Meyer and $C$. perfossilis Krammer all have a less convex dorsal outline and central axial area. Except the above differences, C. proxima differs from C. shudunensis in bigger central area, larger length/width ratio, different raphe type, the lineolae-like areolae in contrast to the elliptical shaped areolae, and also the arched terminal fissures against the

Tab. 3. Morphological characters of Cymbella shudunensis Li et Metzeltin, C. terrafuegiana, $C$. proxima Reimer in Patrick et Reimer, C. baicalensis Skvortzow et Meyer and C. perfossilis Krammer.

\begin{tabular}{|c|c|c|c|c|c|}
\hline \multirow[b]{2}{*}{$\begin{array}{l}\text { Species/ } \\
\text { Feature }\end{array}$} & $\frac{\text { New species }}{\text { C. shudunensis }}$ & \multicolumn{4}{|c|}{ Species for comparison } \\
\hline & $\begin{array}{l}\text { C. shudunensis } \\
\text { Li et Metzeltin }\end{array}$ & $\begin{array}{l}\text { C. terrafuegiana } \\
\text { Krammer }\end{array}$ & $\begin{array}{l}\text { C.proxima } \\
\text { Reimer in } \\
\text { Patrick et } \\
\text { Reimer }\end{array}$ & $\begin{array}{c}\text { C. baicalensis } \\
\text { Skvortzow et } \\
\text { Meyer }\end{array}$ & $\begin{array}{l}\text { C. perfossilis } \\
\text { Krammer }\end{array}$ \\
\hline $\begin{array}{l}\text { Valve length, } \\
\mu \mathrm{m}\end{array}$ & $55-87$ & $64-74$ & $38-120$ & $112-195$ & $48-121$ \\
\hline $\begin{array}{l}\text { Valve width, } \\
\mu \mathrm{m}\end{array}$ & $24-27$ & $18-22$ & $18-24$ & $51-60$ & $20-26$ \\
\hline $\begin{array}{l}\text { Length/width } \\
\text { ratio }\end{array}$ & 3.3 & $\operatorname{Max} 3.6$ & $\operatorname{Max} 5$ & 3.3 & 3.7 \\
\hline $\begin{array}{l}\text { Striae in } \\
10 \mu \mathrm{m}\end{array}$ & $7-12$ & $8-11$ & $7-11$ & Middle 6-7 & $7-12$ \\
\hline $\begin{array}{l}\text { Areolae in } \\
10 \mu \mathrm{m}\end{array}$ & $17-19$ & $19-21$ & $12-18$ & About 8 & $13-18$ \\
\hline Areolae & $\begin{array}{c}\text { Slit-like, Y-, } \\
\text { X- shaped }\end{array}$ & Not know & Slit-like & Not know & Not known \\
\hline Stigmata & $\begin{array}{c}\text { Ventral side: } \\
2-4\end{array}$ & $\begin{array}{c}\text { Ventral side: } \\
2-4\end{array}$ & $\begin{array}{c}\text { Ventral side: } \\
2-5\end{array}$ & $\begin{array}{l}\text { Ventral side: } \\
\quad 2-4\end{array}$ & $\begin{array}{l}\text { Ventral side: } \\
\quad 2-5\end{array}$ \\
\hline $\begin{array}{l}\text { Central } \\
\text { area }\end{array}$ & $\begin{array}{c}\text { Small and } \\
\text { indistinct dorsal }\end{array}$ & $\begin{array}{l}\text { Absent or small } \\
\text { round }\end{array}$ & $\begin{array}{l}\text { Orbicular, 1/3 } \\
\text { width }\end{array}$ & $\begin{array}{l}\text { Orbicular, } \\
\text { 1/3-1/4 width }\end{array}$ & $\begin{array}{c}\text { Irregularly } \\
\text { round, } 1 / 3 \text { width }\end{array}$ \\
\hline $\begin{array}{l}\text { Central } \\
\text { raphe } \\
\text { endings }\end{array}$ & $\begin{array}{c}\text { Round, ventrally } \\
\text { bent }\end{array}$ & Small & $\begin{array}{l}\text { Bulbous, } \\
\text { somewhat } \\
\text { dorsally bent }\end{array}$ & Large & $\begin{array}{c}\text { Distinct, } \\
\text { ventrally bent }\end{array}$ \\
\hline Reference & This study & $\begin{array}{l}\text { KRAMMER } \\
\text { (2002) }\end{array}$ & $\begin{array}{l}\text { KRAMMER } \\
\text { (2002) }\end{array}$ & $\begin{array}{l}\text { KRAMMER } \\
\text { (2002) }\end{array}$ & $\begin{array}{l}\text { KRAMMER } \\
\text { (2002) }\end{array}$ \\
\hline
\end{tabular}


scythe-shaped; $C$. baicalensis is different in the larger size and the much coarser puncta. Cymbella perfossilis can be distinguished by the outline and larger dorsal central area.

Cymbella xingyunnensis resembles to the group around $C$. proxima, but with smaller size than the species included in this group now. All the similar species compared with this new taxa (Tab. 4). Cymbella xingyunnensis is quite similar with $C$. sinensis, belonging to $C$. proxima group. But Cymbella sinensis has larger valve size, coarser puncta, without the observed stigmata. In SEM, $C$. sinensis has C- shaped areolae, the foramina areolae in the pole are arranged in both side of the terminal fissures in external view, in internal view the foramina surround the helictoglossa contrary to the parallel arrangement in Cymbella xingyunnensis. Cymbella parva W. Smith has similar SEM view (Pl. 12, Figs. 8-10, KRAMMER 2002), but this taxa can be separated from the LM view, with smaller width, less dense striae and finer puncta. Cymbella xingyunnensis is also similar to C. compacta Østrup and $C$. turgidula Grunow. The former can be distinguished by the lack of apical pore field

Tab. 4. Morphological characters of Cymbella xingyunensis Li and Gong, C. sinensis Metzeltn et Krammer, C. parva (W. Smith) Kirchner in Cohn, C. compacta Østrup and C. turgidula Grunow

\begin{tabular}{|c|c|c|c|c|c|}
\hline \multirow[b]{2}{*}{$\begin{array}{l}\text { Species/ } \\
\text { Feature }\end{array}$} & \multirow{2}{*}{$\begin{array}{c}\text { New species } \\
\text { C. xingyunensis } \\
\text { Li and Gong }\end{array}$} & \multicolumn{4}{|c|}{ Species for comparison } \\
\hline & & $\begin{array}{l}\text { C. sinensis } \\
\text { Metzeltn et } \\
\text { Krammer }\end{array}$ & $\begin{array}{c}\text { C. parva } \\
\text { (W. Smith) } \\
\text { Kirchner in } \\
\text { Cohn }\end{array}$ & $\begin{array}{c}\text { C. compacta } \\
\emptyset \text { strup }\end{array}$ & $\begin{array}{l}\text { C. turgidula } \\
\text { Grunow }\end{array}$ \\
\hline $\begin{array}{l}\text { Valve length, } \\
\mu \mathrm{m}\end{array}$ & $25-41$ & $48-58$ & $15-47$ & $28-76$ & $30-50$ \\
\hline $\begin{array}{l}\text { Valve width, } \\
\mu \mathrm{m}\end{array}$ & $11.3-13.5$ & $17-18$ & $7-10$ & $11-15$ & $11-14$ \\
\hline $\begin{array}{l}\text { Length/width } \\
\text { ratio }\end{array}$ & 3 & $\operatorname{Max} 2.8$ & $\operatorname{Max} 4.5$ & Max 5.1 & $\operatorname{Max} 3.3$ \\
\hline $\begin{array}{l}\text { Striae in } \\
10 \mu \mathrm{m}\end{array}$ & $13-16$ & $12-13$ & $9-13$ & $10-14$ & $8-14$ \\
\hline $\begin{array}{l}\text { Areolae in } \\
10 \mu \mathrm{m}\end{array}$ & $22-25$ & $15-16$ & $28-30$ & $18-24$ & $22-25$ \\
\hline Areolae & $\begin{array}{l}\text { Elongated, } \\
\text { become round } \\
\text { towards the } \\
\text { centre }\end{array}$ & $\begin{array}{l}\text { C-shaped, } \\
\text { become round } \\
\text { towards the } \\
\text { centre }\end{array}$ & $\begin{array}{l}\text { Elongated, } \\
\text { become round } \\
\text { towards the } \\
\text { centre }\end{array}$ & silt-like & Not know \\
\hline Stigmata & $\begin{array}{l}\text { Ventral side: } \\
\text { one big }\end{array}$ & No & $\begin{array}{l}\text { Ventral side: } \\
\text { one big }\end{array}$ & $\begin{array}{c}\text { Ventral side: } \\
4-8\end{array}$ & $\begin{array}{l}\text { Ventral side: } \\
\quad 1-3\end{array}$ \\
\hline Central area & $\begin{array}{l}\text { Small and } \\
\text { orbicular }\end{array}$ & $\begin{array}{l}\text { Small, orbicular, } \\
1 / 4-1 / 5 \text { width }\end{array}$ & $\begin{array}{l}\text { Absent or } \\
\text { small }\end{array}$ & absent & $\begin{array}{l}\text { Small, rounded, } \\
\text { more on doarsal }\end{array}$ \\
\hline $\begin{array}{l}\text { Central raphe } \\
\text { endings }\end{array}$ & Indistinct & Indistinct & $\begin{array}{l}\text { Distinct, } \\
\text { rounded }\end{array}$ & $\begin{array}{l}\text { Small, slightly } \\
\text { ventral bent }\end{array}$ & $\begin{array}{l}\text { Slightly } \\
\text { rounded }\end{array}$ \\
\hline Reference & This study & $\begin{array}{c}\text { KRAMMER } \\
\text { (2002) }\end{array}$ & $\begin{array}{c}\text { KRAMMER } \\
\text { (2002) }\end{array}$ & $\begin{array}{c}\text { KRAMMER } \\
\text { (2002) }\end{array}$ & $\begin{array}{c}\text { KRAMMER } \\
\text { (2002) }\end{array}$ \\
\hline
\end{tabular}


and 4-8 stigmata on the ventral side. The latter has subrostrate to rostrate valve ends, commonly two stigmata, sometimes one to three stigmata on ventral side. Cymbella xingyunnensis can be distinguished from $C$. subcistula Krammer in valve size, length/ breadth, striae numbers in $10 \mu \mathrm{m}$, stigmata numbers, and central area. Cymbella subcistula varies between 33 and $85 \mu \mathrm{m}$ in length and 13.4-18 $\mu \mathrm{m}$ in width, with maximal length/ breadth ratio $4.8,7-12$ striae in $10 \mu \mathrm{m}$ and 2-5 small stigmata on ventral side.

\section{Ecology}

So far, Cymbella heihainensis has only been found in the surface sediment of Heihai Lake. Heihai Lake is an alpine lake, which is slightly alkaline and base-poor (Tab.1). The associated taxa from the surface sediment on which Cymbella heihainensis was found include Cyclotella distinguenda var. unipunctata (Hustedt) Håkansson et J. R. Carter (42\%), Cyclotella ocellata Pantocsek (13\%), Achnanthes minutissima Kützing (10\%) and small Fragilaria spp. (15\%). The small Cyclotella species indicate an oligotrophic and open water environment in the pelagic zone (Wunsam et al. 1995, CoRELLA et al. 2011). Achnanthes minutissima also shows high abundance in low nutrient and base poor condition (PonAder and PotaPova 2007). Liu et al. (2012) reported from Great Xing' An Mountains in NE China morphologically similar species, i. e. Cymbella cf. arctissima Metzeltin which should be re-examined to establish its identity and relationship to C. heihainensis.

Cymbella shudunensis has only been found in Shudu Lake, which is a high altitude, shallow, oligo-mesotrophic lake with relative high TN but low TP concentration (Tab. 1). In Shudu Lake, the diatom community from surface sediment is diverse, and mainly dominated by Cyclotella stelligera (Cleve et Grunow) Van Heurck (17\%), Fragilaria pinnata Ehrenberg (15\%), Achnanthes minutissima (9\%), Tabellaria flocculosa (Roth) Kützing (5\%) and Gomphonema minutum (C. Agardh) C. Agardh (4\%). The high diversity of diatom species may reflect the shallow lake conditions with rich available habitats. Cyclotella stelligera and Tabellaria flocculosa are known as oligo-mesotrophic taxa (LITTLE et al. 2000, LiLham 1971). Cymbella shudunensis may prefer mesotrophic water condition.

The new species Cymbella xingyunnensis has been found in Xingyun Lake, base-rich, and meso-eutrophic (with relative high TN and TP concentration). The associate diatom assemblage of surface sediment in Xingyun Lake showed the dominance of Cyclostephanos dubius (Fricke) Round (49\%), Fragilaria crotonensis Kitton (28.5\%) and Aulacoseira granulata (Ehrenberg) Simonsen (10\%). This new taxon was also found in Erhai Lake, another meso-eutrophic lake in Yunnan Province (with $0.592 \mathrm{mg} \mathrm{L}^{-1} \mathrm{TN}$ and $0.045 \mathrm{mg} \mathrm{L}^{-1}$ TP), while Erhai Lake was characterized by Fragillaria crotonensis (43\%), Aulacoseira ambigua (Grunow) Simonsen (28\%), Cyclostephanos dubius (11\%) and Cyclotella ocellata (10\%). Cyclostephanos dubius and Fragillaria crotonensis are indicators of eutrophic (BRADSHAW and ANDERSON 2003, LOTTER 1998). Cymbella xingyunnensis may be tolerant to nutrient-rich water. The most resemble taxa of Cymbella xingyunnensis is $C$. sinensis, which was considered unique to the Yunnan Plateau (Li et al. 2007b).

Further investigation in this area, especially in the habitats which the species prefer, will be necessary to establish a more comprehensive view of their biogeography, and contribute to the environmental-change research in this region. The internal view of $C$. heihainensis and $C$. shudunensis should be supplemented in future study. 


\section{Acknowledgements}

This work was supported by the project of NIGLAS, the project of CAS (KZCX2-EW-QN312), (2011-NIGLAS-002), and National Science Foundation of China (Grant No. 41172152, 40772204). Special thanks to Dr. Enlou Zhang and Dr. Rong Wang for their help.

\section{References}

Aber, J. D., Magill, A., Mcnulty, S. G., Boone, R. D., Nadelhoffer, K. J., Downs, M., HALLETT, R., 1995: Forest biogeochemistry and primary production altered by nitrogen saturation.Water, Air and Soil Pollution 85, 1665-1670.

BAO, W., WANG, Q., REIMER, C. W., 1992: Diatoms from the Changbaishan mountain area (In Chinese). Bulletin of Botanical Research 12, 125-143.

BRADSHAW, E. G., ANDERSON, N. J., 2003: Environmental factors that control the abundance of Cyclostephanos dubius (Bacillariophyceae) in Danish lakes, from seasonal to century scale. European Journal of Phycology 38, 265-276.

Chen, Y., 1998: The fishes of the Hengduan Mountains region (In Chinese). Science Press, Beijing.

Corella, J. P., Amrani, A. E., Sigró, J., Morellón, M., Rico, E., Valero-Garcés, B. L., 2011: Recent evolution of Lake Arreo, northern Spain: influences of land use change and climate. Journal of Paleolimnology 46, 469-485.

Ebina, J., TsutsuI, T., ShIRAI, T., 1983: Simultaneous determination of total nitrogen and total phosphorus in water using peroxodisulfate oxidation. Water Research 17, 17211726.

FAN, Y., WANG, Q., BAO, W., 1993: Investigation on Cymbellaceae from northeastern China (In Chinese). Natural Sciences Journal of Harbin Normal University 9, 82-106.

Fan, Z., Liu, S., Liu, Y., Liao, L., Zhang, X., Yue, B., 2012: Phylogeography of the South China field mouse (Apodemus draco) on the Southeastern Tibetan Plateau reveals high genetic diversity and glacial refugia. PLoS ONE, e38184.

Galloway, J. N., Cowling, E. B., 2002: Reactive nitrogen and the world: 200 years of change. Ambio 31, 64-71.

Hirano, M., 1972: Diatoms from the Hida Mountain Range in the Japan Alps. Contributions from the Biological Laboratory, Kyoto University 24, 9-30, 4 pls.

Jena, M., Ratha, S. K., AdhiKary, S. P., 2006: Diatoms (Bacillariophyceae) from Orissa State and Neighbouring Regions, India. Algae 21, 377-392.

Jüttner, I., Gurung, S., Sharma, C., Sharma, S., 2010: Morphology of new taxa in the Cymbella aspera and Cymbella neocistula groups, Cymbella yakii sp. nov., and Cymbella cf. hantzschiana from Everest National Park, Nepal. Polish Botanical Journal 55, 73-92.

JÜTTNER, I., CoX, E. J., ORMEROD, S. J., 2000: New or poorly known diatoms from Himalayan streams. Diatom Research 15, 237-262.

Krammer, K., 2002: Diatoms of Europe, 3, Cymbella. A. R. G. Gantner Verlag K. G., Ruggell. 
LeE, J. H., Gotoh, T., Chung, J., 1993: Cymbella orientalis sp. nov., a freshwater diatom from the Far East. Diatom Research 8, 99-108.

LI, Y., Gong, Z., SHEn, J., 2007a: Freshwater diatoms of eight lakes in the Yunnan Plateau, China. Journal of Freshwater Ecology 22, 169-171.

Li, Y., Gong, Z., XIE, P., ShEn, J., 2007b. Floral survey of the diatom genera Cymbella and Gomphonema (Cymbellales, Bacillariophyta) from the Jolmolungma Mountain region of China. Cryptogamie Algologie 28, 209-244.

LI, Y., SHI, Z. X., XIE, P., Rong, K., 2003b: New varieties of Gomphonema and Cymbella (Bacillariophyta) from Qinghai Province (In Chinese). Acta Hydrobiologica Sinica 27, 147-148.

LI, J., WeI, L., ZHENG, M. 2003a: A new sepceis of Cymbella agardh (Bacillariophyta) from northwest Xizang (Tibet) and its microstructure. Acta Micropalaeontologica Sinica 21, 435-438.

LI, Y., XIE, P., Gong, Z., SHI, Z., 2003c: Gomphonemaceae and Cymbellaceae (Bacillariophyta) from Hengduan Mountains region (Southwest China). Nova Hedwigia 76, 307-336.

Li, Y., XIE, P., Gong, Z., Shi, Z., 2004; A survey of the Gomphonemaceae and Cymbellaceae (Bacillariophyta) from the Jolmolungma Mountain (Everest) Region of China. Journal of Freshwater Ecology 19, 189-194.

LiLHAM, P., 1971: A hypothesis concerning silica and the freshwater planktonic diatoms. Limnology and Oceanography 16, 10-18.

Little, J. L., Hall, R. I., Quinlan, R., Smol, J. P., 2000: Past trophic status and hypolimnetic anoxia during eutrophicaton and remediation of Gravenhurst Bay, Ontario: comparison of diatoms, chironomids, and historical records. Canadian Journal of Fisheries and Aquatic Sciences 57, 333-341.

LIU, Y., FAN, Y., WANG, Q., 2012: Newly recorded species in cymbellaceae and gomphonemataceae from Great Xing' An Mountains, China (In Chinese). Acta Hydrobiologica Sinica 36, 498-508.

LotTer, A. F., 1998: The recent eutrophication of Baldeggersee (Switzerland) as assessed by fossil diatom assemblages. The Holocene 8, 395-405.

Metzeltin, D., Lange-Bertalot, H., Nergui, S., Li, Y., 2009: Diatoms in Mongolia and Sichuania lacustris spec. et gen. nov. Iconographia Diatomologica 20. A. R. Gantner Verlag, Ruggell.

Myers, N., Mittermeier, R. A., Mittermeier, C. G., Fonseca, G. A. B., Kent, J., 2000: Biodiversity hotspots for conservation priorities. Nature 403, 853-858.

Nautiyal, P., Nautiyal, R., Kala, K., Verma, J., 2004: Taxonomic richness in the diatom flora of Himalayan streams (Garhwal, India). Diatom 20, 123-132.

NyDAHL, F., 1978: On the peroxodisulphate oxidation of total nitrogen in waters to nitrate. Water Research 12, 1123-1130.

Ponadera, K. C., Potapova, M. G., 2007: Diatoms from the genus Achnanthidium in flowing waters of the Appalachian Mountains (North America): Ecology, distribution and taxonomic notes. Limnologica 37, 227-241. 
Skuja, H., 1937: Algae. In: Handel-MazzetTi, H. (ed.), Symbolae Sinicae. Botanische Ergebnisse der expedition der Akademic der Wissenschaften in Wien nach Südwest-China 1914-1918, 1. J, 1-106. Springer, Vienna.

Smol, J. P., Stoermer, E. F. (eds.), 2010: The diatoms: applications for the environmental and earth sciences. Cambridge University Press.

Wunsam, S., Schmid, T. R., KLEE, R., 1995: Cyclotella-taxa (Bacillariophyceae) in lakes of the Alpine region and their relationship to environmental variables. Aquatic Sciences 57, 360-386.

YANG, Q., 1983: The natural zone of the Hengduan Mountains. Compilation report on the Hengduan Mountains of the Qinghai-Xizang Plateau (In Chinese) 1, 96-105. Yunnan Press, Yunnan.

YAnG, X., Anderson, N. J., Dong, X., Shen, J., 2008: Surface sediment diatom assemblages and epilimnetic total phosphorus in large, shallow lakes of the Yangtze floodplain: their relationships and implications for assessing long-term eutrophication. Freshwater Biology 53, 1273-1290.

You, Q., Li, H., WANG, Q., 2005: Preliminary Studies on Diatoms from Kanasi in Xinjiang Uighur Autonomous (In Chinese). Journal of Wuhan Botanical Research 23, 247-256.

You, Q., WANG, Q., SHI, Z., 2008: Newly recorded species of Cymbellaceae (Bacillariophyta) in China (In Chinese). Acta Hydrobiologica Sinica 32, 735-740.

ZHANG, R., 1997: The physical geography of the Hengduan Mountains. Science Press, Beijing.

ZHU, H., CHEN, J., 1994: Study on the diatoms of the Wuling Mountain Region (In Chinese). In: SHI, Z. (ed.), Compilation of report on survey of algal resources in southwestern China, 79-130. Science Press, Beijing. 